\title{
Variability in Isozyme Patterns for Virulence among the Rhizoctonia solani Isolates Causing Banded Leaf and Sheath Blight in Maize
}

\author{
M. Madhavi*, P. Narayan Reddy, K. Manohar and Ch. Aruna Kumari \\ Department of Plant Pathology, Agricultural College, Polasa, Jagtial (Dist), Telangana \\ State, India 505529 \\ *Corresponding author
}

\begin{tabular}{|c|c|}
\hline & A B S T R A C T \\
\hline $\begin{array}{l}\text { Ke e y w o r d s } \\
\text { Isozyme, esterase, } \\
\text { peroxidise, } \\
\text { polyphenol } \\
\text { oxidases, } \\
\text { Rhizoctonia solani } \\
\text { isolates, PAGE }\end{array}$ & \multirow{3}{*}{$\begin{array}{l}\text { Isozyme analysis/isozyme patterns of esterases and peroxidase of twenty } \\
\text { eight isolates of the pathogen } R \text {. solani collected from maize (27) and one } \\
\text { isolate from rice were used to study the variability among the isolates of } R \text {. } \\
\text { solani through Polyacrylamide Gel Electrophoresis (PAGE) ) and } \\
\text { polyphenol oxidases by Spectrophotometer.. The study revealed that the } \\
\text { isolates of } R \text {. solani showed considerable diversity in the production of } \\
\text { enzyme which plays a major role in pathogenicity. The electrophoretic } \\
\text { patterns of isozymes provided a good indication of genetic diversity among } \\
\text { the isolates. The results obtained from isozyme analysis in this study } \\
\text { suggested that isozyme analysis could be useful in genetic diversity studies } \\
\text { and identification of various } R \text {. solani isolates. }\end{array}$} \\
\hline Article Info & \\
\hline $\begin{array}{l}\text { Accepted: } \\
\text { 26 December } 2017 \\
\text { Available Online: } \\
\text { 10 January } 2018\end{array}$ & \\
\hline
\end{tabular}

\section{Introduction}

Maize (Zea mays L.) is a $\mathrm{C}_{4}$, and third most important cereal crop in the world's agricultural economy. It is used as a source of food, feed and industrial products. In spite of having high yield potential it is susceptible to several biotic stresses. The banded leaf and sheath blight (BLSB) caused by Rhizoctonia solani f. sp. sasakii Exner, (Tel: Thanatephorus sasakii (Shirai) $\mathrm{Tu}$ and Kimbro) is a very destructive disease of maize and is gaining economic importance especially in several hot and humid tropical maize growing areas worldwide (Akhtar et al., 2009). The pathogen causes grain yield loss to an extent of $40.0 \%$. Being variable and belongs to ubiquitous group, it had a wide host range. In recent years, the disease occurrence was wide spread in almost all major maize growing areas of Telangana and Andhra Pradesh states with different intensities in most of the popular cultivars especially in rice fallow maize (zero tillage) cropping system. 
The disease has become a major constraint in breeding programme because of the nonavailability of widely adapted and stable source of resistance to BLSB. The variability in the pathogen considerably complicates the host range and resistance screening for host material. Without a clear knowledge of strains present in a particular cropping ecosystem it is very difficult to conclude the etiology as well as to select varieties for areas under this ecosystem. The knowledge on existence of pathotypes/ physiological races can be achieved based on the distinct variations in the pathogen in relation to their pathogenicity. Since $R$. solani is a variable pathogen and had a wide host range and so far, no attempt has been made to define variability of $R$. solani in relation to spatial distribution in Telangana and Andhra Pradesh states, the differences in isozyme patterns underlying among $R$. solani populations collected from different maize growing districts of Telangana State will provide a useful information of the pathogen.

An isozyme, a direct expression of genotype can be used as an indicator of genetic relationship within related populations. One of the tools in studying mechanisms involved in genetic diversity in fungal populations is the use of isozymes. Isozyme analysis is a powerful biochemical technique with numerous applications in Plant Pathology. Mycologists and Plant Pathologists adopted the procedure to settle taxonomic disputes and analyze genetic variability among the plant pathogens (Micales and Bonde, 1995). It has a potential for resolving relationship among imperfect fungi (Bosland and Williams, 1987). Studies on isozyme patterns of polyphenol oxidase and esterase have been used to know the variability among the various plant pathogens (Horvath and Vargas, 2004). For fungal isolates with few or no readily distinguishable morphological features, such as $R$. solani biochemical probes may provide markers useful for classification.
Electrophoretic banding patterns of isozymes are usually predictable based on their genetic background. The selection of enzyme systems is very important in detecting the variability among plant pathogens. Any study that uses broad classes of enzymes such as esterases, peroxidases, alkaline / acid phosphotases and polyphenol oxidases will display disproportionally high levels of intra-specific variation. Hence, in the present study variability in electrophoretic isozyme patterns of esterases and peroxidises; and polyphenol oxidases by spectrophotometer among the population of BLSB fungus Rhizoctonia solani (RS) was assessed for easy breeding task.

\section{Materials and Methods}

Twenty seven samples of maize exhibiting BLSB symptoms were collected from nine major maize growing districts of Telangana and Andhra Pradesh states at the rate of three different mandals in each district. The pathogen $R$. solani isolates were isolated, identified and designated as RS1 to RS27. One isolate from rice collected from RangaReddy district was designated as RS28 (Table 1).

Isozyme patterns of peroxidases and esterases of all the twenty eight isolates of the pathogen $R$. solani were studied (Laemmli, 1970) through Polyacrylamide Gel Electrophoresis (PAGE) and polyphenol oxidases by Spectrophotometer.

\section{Cultivation of fungus for electrophoretic studies}

Agar discs of $5 \mathrm{~mm}$ diameter containing actively growing hyphae was used as inoculum. The discs were cut from the periphery of one week old culture on PDA with the help of a sterile cork borer. These culture discs were transferred to $250 \mathrm{ml}$ conical flasks containing $50 \mathrm{ml}$ of sterile 
Potato Dextrose Broth (PDB) medium and incubated for 10 days at $27+2^{\circ} \mathrm{C}$.

\section{Extraction of Intra- cellular mycelial enzymes}

After incubation of the fungus on PDB for 10 days, the mycelial mats developed on liquid broth were separated by filtering through Whatman No. 1 filter paper. The mats were washed thoroughly with distilled water and homogenized with $0.1 \mathrm{M}$ Tris- $\mathrm{HCl}$ buffer of pH 7.5 using pre-chilled mortar and pestle. The homogenates were centrifuged at 3,500 rpm for 20 minutes in a refrigerated centrifuge (Eppendorf AG, Germany). The clear supernatants were separated and used in electrophoretic studies. Enzyme extraction was improved when sterile sea sand was used to macerate the fungal mats.

\section{Electrophoretic assay}

Polyacrylamide gel was used as the supporting medium for separation of enzymes fractions. The electrophoretic method followed in the present investigation was Polyacrylamide slab gel electrophoresis (PAGE) system as given by Sambrook et al., (1989). Native PAGE was employed to study the isozyme patterns in the collected isolates.

\section{Staining for detection of enzyme bands}

After performing the native PAGE the gels were taken off from the sandwiches carefully and stained with suitable stains to detect peroxidases and esterase isozyme bands.

\section{a) Esterases (Shaw and Prasad, 1970)}

The gel was immersed in the staining solution of Phosphate buffer ( $\mathrm{pH}$ 6.0) containing 1\% $\alpha$ naphthyl acetate and $\beta$-naphthyl acetate and fast green (Shaw and Prasad, 1970) and incubated at $30^{\circ} \mathrm{C}$ for 30 minutes in dark. The gels were destained in 7 per cent acetic acid for 30 minutes, photographed using gel documentation system and preserved in $2 \%$ acetic acid solution.

\section{b) Peroxidases (Mahmoud et al.,2007)}

The gels were incubated in $0.05 \mathrm{M}$ acetate buffer ( $\mathrm{pH} 5.0$ ) containing $65 \mathrm{mg}$ of odianisidine dissolved in $5 \mathrm{ml}$ of ethanol. After staining the gels were destained in 7 per cent acetic acid for 30 minutes, photographed through gel documentation system and stored in 2 per cent acetic acid solution.

\section{c) Polyphenol oxidases (Erhan Astarci, 2003)}

Polyphenol oxidase activity was measured spectrophotometrically. Culture supernatant was used as crude enzyme source. $100 \mathrm{mM}$ catechol in $0.2 \mathrm{M}$ phosphate buffer at $\mathrm{pH} 7.0$ was used as substrate (Erhan Astarci, 2003). The reaction mixture contained $1 \mathrm{ml}$ of $0.2 \mathrm{M}$ phosphate buffer ( $\mathrm{pH}$ 7.0), $0.5 \mathrm{ml}$ culture supernatant and $0.5 \mathrm{ml}$ substrate solution (100 $\mathrm{mM}$ ) incubated at $50{ }^{\circ} \mathrm{C}$ for 3 minutes. The reference cuvette contained buffer instead of enzyme and change in absorbance was followed at $410 \mathrm{~nm}$ and initial reaction rate was used to determine the enzyme activity. The enzyme activity was expressed as $\mu \mathrm{g}$ ppo/ mg proteins.

One unit of enzyme (U) is defined as the amount of the enzyme required to obtain 0.001 Optical Density (OD) change at $410 \mathrm{~nm}$.

\section{Zymograms and Similarity Index (SI) for esterases and peroxidase}

The zymograms were prepared indicating the Relative mobility ( $\mathrm{Rm}$ ) values of isozyme bands. The differences in isozyme patterns of esterase and peroxidases enzymes were quantitatively expressed in terms of relative mobility $(\mathrm{Rm})$ values. 
Relative mobility $(\mathrm{Rm})=$

Distance travelled by enzyme front

Distance travelled by dye front

Similarity index (SI) and genetic distance values were calculated using the following formula.

$\mathrm{SI}=$

No. of pairs of similar bands

No. of different bands + No. of pairs of similar bands

Genetic distance $=100-$ Similarity Index

\section{Results and Discussion}

\section{Esterase}

The banding pattern of esterase, their relative mobility, density and intensity were recorded by zymogram. The data presented in the Table 2 , provides convenient means for comparing the banding patterns among all the $R$. solani isolates. The migration distances (from the origin to the cathode) of all bands from each isolate were compared with those of the bands from every other isolate. The comparison between the isolates was made based on relative mobility $(\mathrm{Rm})$ values, density of bands, similarity index and genetic distance values. The $R$. solani isolates differed greatly with respect to esterase isozyme activity among them. A total of 57 esterase isozyme bands were produced in all the isolates including very faint bands (Plate 1 ).

The variation within these isozyme bands of different isolates usually involved in position of faint, minor bands or the comparative thickness of density of bands. Two bands numbered 7 and 10 were frequent, prominent and dense to medium and were found in most of the isolates. The $\mathrm{Rm}$ values of these isolates ranged from as low as 0.06 to as high as 0.55 . Band number 1 with $\mathrm{Rm}$ value of 0.06 was observed by the isolates RS1(Medak), RS15(Warangal), RS24(West Godavari), RS25 and RS 27(Kurnool). The maize isolate RS11 from Khammam district and rice RS28 has produced their fourteenth band with $\mathrm{Rm}$ value of 0.44 . But the final band with $\mathrm{Rm}$ value 0.55 was specific to the virulent isolate from the study i.e RS11 from Khammam district. However the isolate RS17 from Krishna district has produced maximum number of isozyme bands followed by the isolates RS12 and RS16 compared to rest of the isolates. Similarity index values between the isolates ranged from 0.43 to 1.00 . Maximum similarity index values (1.00) were observed between the isolate combinations RS1 (Telangana) and RS27 (Rayalaseema); RS13 (Telangana) and RS21(Andhra); RS 24(Andhra) and RS25 (Rayalaseema). Minimum similarity index value of 0.43 was observed between the isolates RS12 (Telangana)-RS17 (Andhra Pradesh) (Table $3)$.

The esterase isozyme was estimated, depending on presence (1) or absence (0) of bands in each isolates by visual scoring and set in a binary matrix. Enzymatic similarities among the isolates were determined based on Jaccard's coefficient. A dendrogram was then constructed based on similarity levels generated from cluster analysis using the Unweighted Pair Group Method of the Arithmetic average (UPGMA) with a SAHN module of NTSYspl software version 2.1.

The zymogram constructed based on similarity levels generated from cluster analysis represents that all the $28 R$. solani isolates were grouped into 2 main clusters at 0.67 coefficient distance (Fig.1). As per the dendrogram, maximum isolates showed higher similarity value i.e more than $85 \%$ however isolates (RS1 and RS 27; RS5and RS7; RS4, 
RS6 and RS9; RS13 and RS21; RS 24 and RS25) have shown $100 \%$ similarity compared to rest of the isolates tested.

Genetic distance values was also more in the isolate combination RS12-RS17. Maximum genetic distance (99.44) was observed between the isolate combinations RS10-RS12; RS11-RS12; RS12-RS19; RS12-RS23; RS12RS26; RS17-RS18 and RS17-RS25, while minimum genetic distance (99.0) values were noticed in the combinations given above for which similarity index values were maximum (100).

\section{Peroxidase}

The migration pattern of peroxidase among these $R$. solani isolates differed in their number, migration distance from the origin and width of each band along length of the gel. A total of 48 isozyme bands of peroxidase were observed among all the 28 isolates of $R$. solani. The band number 4 was medium to dense and found prominent among the isolates RS2(Medak), RS13, RS14, RS15 (Warangal) and RS17 (Krishna). The three bands 16, 18 and 19 were intense and thick on the polyacrylamide gel and were present in the maize isolates RS11(Khammam), RS16 (Krishna) and rice isolate RS28 (Plate 2 ).

The $\mathrm{Rm}$ values of peroxidase isozyme scored by the $28 R$. solani isolates ranged from 0.26 to 0.94 . Band number 1 with $\mathrm{Rm}$ value of 0.26 was specific to the isolate RS4, RS8, RS9 and RS22 (Table 4). The 4th band with $0.35 \mathrm{Rm}$ value was present in the isolates RS13, RS14, RS15and RS17. The bands 6 and 20 were observed only in the isolates of RS24 (West Godavari) and RS16 (Krishna) with 0.39 and $0.69 \mathrm{Rm}$ values respectively. The maize isolates RS11(Khammam), RS26 (Kurnool) and rice RS28 had band number 19 with 0.65 $\mathrm{Rm}$ value. Similarly, band 15th is common among the isolates RS18, RS19, RS20, and RS27 with $0.55 \mathrm{Rm}$ value. The maize isolate
RS12 from Khammam district has produced a unique dense band with $0.94 \mathrm{Rm}$ value. However, the maize isolate RS17 from Krishna district has produced more number of peroxidise isozyme bands. The similarity index values between the isolates for peroxidase patterns ranged from 0.66 to 1.00 . Cent per cent (1.00) similarity was observed between the isolate combinations RS8, RS9 and RS 22; RS5 and RS6; RS19 and RS20; RS13 and RS15; RS11 and RS26. The other isolates RS10-RS11; RS11-RS17; RS17RS24; and RS17- RS26 shared minimum (0.66) similarity index (Table 5).

The phylogenetic tree resulting from cluster analysis based on isozyme data, revealed that the $R$. solani isolates separated into two major clusters which were separated at a distance of 0.79 on coefficient value scale. In cluster II, the isolate RS 10 (Khammam) had separated at a coefficient value of 0.79 (Fig.2).

The zymogram tree has further divided the cluster I with 27 isolates into 4 groups i.e IA, IB, IC and ID. The isolate RS24 from West Godavari in Group IA had separated at 0.80 coefficient value. In group IB, the virulent isolate, RS11 from Khammam district of Telangana shared cent percent similarity with the isolate RS 26 from Kurnool district of Andhra Pradesh and together these maize isolates shared $95.4 \%$ similarity coefficient with the rice isolate RS 28. The isolate RS17 from Krishna district of Andhra Pradesh showed similarity with the isolates, RS13RS15; and RS14 from Warangal district of Telangana at 0.87 coefficient value.

Group ID is further divided into 2 sub groups i.e. ID-1 and ID-2.In group ID-1 isolates RS1(Telangana) and RS7 (Andhra Pradesh) are similar at $95.4 \%$ similarity coefficient and shared similarity with the isolate RS21 at 0.93 coefficient value. Under ID-2 group, the isolates RS8, RS9 and RS22; RS5 and RS6 have shown $100 \%$ similarity. Similarly the 
similarity index shared between the isolates RS2 and (RS8, RS9 and RS22); RS4 and (RS5, RS6) was 95.4\%. Group ID-2 has two more minor clusters i.e. ID-2 (a) and ID-2(b). In group ID- 2(b) $100 \%$ similarity was observed between the isolates, RS19 and RS20 and shared $95.4 \%$ similarity with isolate RS18. Together, these isolates with isolate RS27 had shown $94 \%$ similarity.

Genetic distance values were found to be maximum (99.34) in between the isolate combinations RS10 (Khammam) - RS17 (Krishna); RS11(Khammam) RS17(Krishna); RS17(Krishna) - RS24 (West Godavari) and RS17 (Krishna) - RS26 (Kurnool). Least genetic distance values (99.0) were recorded in between the isolate combinations mentioned above for which the similarity index values were maximum (1.00).

\section{Estimation of polyphenol oxidases}

From the Table 6, it is evident that all the 28 isolates of $R$. solani increased the ppo activity significantly over time. Among the 27 maize isolates, significantly higher quantities were observed in isolate RS11 from Khammam district with 0.080 quantity of ppo followed by RS16 (0.074), RS 12 (0.071) RS17 (0.053) at OD value above 0.050 to 0.080 value and lowest quantity of (0.004) was produced by the isolate RS21 from Guntur district at below 10 OD value.

However the rice isolate RS28 has recorded highest (0.097) ppo activity compared to all the maize isolates and significantly differed from the maize isolates except for RS11, RS12 (from Khammam) and RS 16 (Vatsavai mandal of Krishna district) which were at par with each other.

The results showed that increase in absorbance and formation of brown colour in samples when assayed in catechol was due to the existence of the enzyme, not because of a compound that exists in the growth medium of fungus. In other words, the oxidation of catechol substrate was due to the existence of polyphenol oxidase. So, it can be suggested that all the $R$. solani isolates have produced polyphenol oxidase enzyme.

In the present study, diversity in isozyme patterns was evident within $R$. solani isolates obtained from various geographical locations in Telangana and Andhra Pradesh states. Based on isozyme patterns of peroxidase and esterase, each isolate could be separated based on the intensity and relative mobility of different isozymes.

The degree of relationship as reflected in the banding patterns of the peroxidise isozyme tested among the isolates of $R$. solani was depicted as zymogram. The isolates RS2, RS13, RS14, RS15 and RS17 from Doulatabad, Janagoan, Atmakur, Hasanparthy and Nuziveedu mandals have produced common band with relative mobility of 0.35 .The minimum similarity index $(66 \%)$ and maximum genetic distance value $(34 \%)$ was observed in the isolate combinations of RS17RS24; RS17-RS26.

It is evident from the results that the isolates of $R$. solani varied with respect to their esterase banding pattern. The band numbers 7 and 10 with relative mobility values were common to most of the isolates tested. But the fifteenth band was confined to two isolates RS11(maize) and RS28 (rice). The final band which is a low molecular weight band with relative mobility value of 0.55 was specific to the virulent isolate RS11 showing maximum / more enzyme activity compared to rest of the isolates. From the dendrogram obtained by cluster analysis of esterase banding patterns, which separated all the 28 isolates into two major clusters, in which cluster B had only one isolate i.e. RS12 from Yellandu mandal of Khammam distrct and the rice isolate RS28 clubbed with maize isolate RS11 in group A. 
Table.1 Details of Rhizoctonia solani f sp sasakii isolates collected from major maize growing districts of Telangana and Andhra Pradesh States

\begin{tabular}{|c|c|c|c|c|c|}
\hline S.No. & Isolates & $\begin{array}{l}\text { Place } \\
\text { collection }\end{array}$ & District & State & Variety/Cultivar \\
\hline 1 & RS1 & Pragnyapur & Medak & Telangana & Kaveri-225 \\
\hline 2 & RS2 & Doulatabad & Medak & Telangana & Pioneer-30V92 \\
\hline 3 & RS3 & Gajwel & Medak & Telangana & Kanchana \\
\hline 4 & RS4 & Armur & Nizamabad & Telangana & C-Tex \\
\hline 5 & RS5 & Kamareddy & Nizamabad & Telangana & Kaveri \\
\hline 6 & RS6 & Mortad & Nizamabad & Telangana & Kanchana \\
\hline 7 & RS7 & Jagityal & Karimnagar & Telangana & C-Tex/Prince \\
\hline 8 & RS8 & Metpally & Karimnagar & Telangana & Pioneer \\
\hline 9 & RS9 & Raichal & Karimnagar & Telangana & Kaveri Gold \\
\hline 10 & RS10 & Bonakal & Khammam & Telangana & Kanchana \\
\hline 11 & RS11 & Chintakani & Khammam & Telangana & Pioneer \\
\hline 12 & RS12 & Yellandu & Khammam & Telangana & Kaveri /C-Tex \\
\hline 13 & RS13 & Janagoan & Warangal & Telangana & Yecca \\
\hline 14 & RS14 & Atmakur & Warangal & Telangana & Kanchana \\
\hline 15 & RS15 & Hasanparthy & Warangal & Telangana & Pioneer \\
\hline 16 & RS16 & Vatsavai & Krishna & Andhra Pradesh & Kaveri-50 \\
\hline 17 & RS17 & Tiruvur & Krishna & Andhra Pradesh & Yecca \\
\hline 18 & RS18 & Nuziveedu & Krishna & Andhra Pradesh & Pioneer-30V 92 \\
\hline 19 & RS19 & Tenali & Guntur & Andhra Pradesh & Pioneer/Kargil \\
\hline 20 & RS 20 & Mangalgiri & Guntur & Andhra Pradesh & Kaveri 255 \\
\hline 21 & RS 21 & Kolipara & Guntur & Andhra Pradesh & Yecca \\
\hline 22 & RS22 & Eluru & West Godavari & Andhra Pradesh & Pioneer-30V 92 \\
\hline 23 & RS23 & Jangareddygudem & West Godavari & Andhra Pradesh & Kanchana \\
\hline 24 & RS24 & Jeelugumilli & West Godavari & Andhra Pradesh & Kaveri-255 \\
\hline 25 & RS25 & Nandikotkur & Kurnool & Andhra Pradesh & Kaveri Gold \\
\hline 26 & RS26 & Atmakur & Kurnool & Andhra Pradesh & Kargil \\
\hline 27 & RS27 & Thatipadu & Kurnool & Andhra Pradesh & Pioneer \\
\hline 28 & $\begin{array}{l}\text { RS28 } \\
\text { (Rice) }\end{array}$ & Rajendranagar & RangaReddy & Telangana & BPT-5204 \\
\hline
\end{tabular}


Table.2 Relative mobility (Rm) values of esterase of $R$. solani isolates

\begin{tabular}{|c|c|c|c|c|c|c|c|c|c|c|c|c|c|c|c|c|c|c|c|c|c|c|c|c|c|c|c|c|c|}
\hline No. & $\mathbf{R m}$ & RS1 & RS2 & RS3 & RS4 & RS5 & RS6 & RS7 & RS8 & RS9 & RS10 & RS11 & RS12 & RS13 & RS14 & RS15 & RS16 & RS17 & RS18 & RS19 & RS20 & RS21 & RS22 & RS23 & RS24 & RS25 & RS26 & RS27 & RS28 \\
\hline 1 & 0.06 & 0.06 & & & & & & & & & & & & & & 0.06 & & & & & & & & & 0.06 & 0.06 & & 0.06 & \\
\hline 2 & 0.16 & & & & & & & & 0.16 & & & & 0.16 & 0.2 & & & & & 0.16 & & & 0.16 & & & & & & & \\
\hline 3 & 0.19 & & & 0.19 & 0.19 & & 0.19 & & & 0.19 & & & & & & & 0.19 & 0.19 & & & & & & 0.19 & & & & & \\
\hline 4 & 0.21 & & & & & & & & & & & & & & & & & & & & & & & & & & & & \\
\hline 5 & 0.23 & & & & & 0.23 & & 0.23 & & & & & 0.23 & & & & & & & & & & & & & & & & \\
\hline 6 & 0.24 & & & & & & & & & & & & & & & & 0.24 & 0.24 & & & & & & 0.24 & & & & & 0.24 \\
\hline 7 & 0.27 & & 0.27 & 0.27 & & & & & 0.27 & & & & & & 0.27 & & & & & 0.27 & & & & & 0.27 & 0.27 & & & \\
\hline 8 & 0.29 & & & & & & & & & & 0.29 & & & & & & & & & & & & & & & & 0.29 & & \\
\hline 9 & 0.31 & & & & & & & & & & & & & & & 0.31 & & 0.31 & & 0.31 & 0.31 & & & & & & & & \\
\hline 11 & 0.35 & & & & & & & & & & & & 0.35 & & & & & & 0.35 & & & & & & & & & & \\
\hline 12 & 0.37 & & & & & & & & & & & & & & & & & & & & & & & & & & 0.37 & & \\
\hline 13 & 0.39 & & & & & & & & & & 0.39 & & & & & & & 0.39 & & & & & & & & & & & \\
\hline 14 & 0.4 & & & & & & & & & & & & 0.40 & & & & 0.40 & & & & & & & & & & & & \\
\hline 15 & 0.44 & & & & & & & & & & & 0.44 & & & & & & & & & & & & & & & & & 0.44 \\
\hline 16 & 0.55 & & & & & & & & & & & 0.55 & & & & & & & & & & & & & & & & & \\
\hline
\end{tabular}


Table.3 Similarity index values of esterase patterns of $R$. solani isolates

\begin{tabular}{|c|c|c|c|c|c|c|c|c|c|c|c|c|c|c|c|c|c|c|c|c|c|c|c|c|c|c|c|c|}
\hline & RS1 & \begin{tabular}{|l|} 
RS2 \\
\end{tabular} & RS3 & RS4 & RS5 & RS6 & RS7 & \begin{tabular}{|l|} 
RS8 \\
\end{tabular} & \begin{tabular}{|l|} 
RS99 \\
\end{tabular} & RS10 & RS11 & RS12 & RS13 & RS14 & RS15 & RS16 & \begin{tabular}{|l|} 
RS17 \\
\end{tabular} & RS18 & RS19 & RS20 & RS21 & \begin{tabular}{|l|} 
RS22 \\
\end{tabular} & RS23 & RS24 & RS25 & RS26 & RS27 & RS28 \\
\hline RS1 & 1.00 & & & & & & & & & & & & & & & & & & & & & & & & & & & \\
\hline RS2 & 0.93 & 1.00 & & & & & & & & & & & & & & & & & & & & & & & & & & \\
\hline RS3 & 0.87 & 0.93 & 1.00 & & & & & & & & & & & & & & & & & & & & & & & & & \\
\hline RS4 & 0.93 & 0.87 & 0.93 & 1.00 & & & & & & & & & & & & & & & & & & & & & & & & \\
\hline RS5 & 0.93 & 0.87 & 0.81 & 0.87 & 1.00 & & & & & & & & & & & & & & & & & & & & & & & \\
\hline RS6 & 0.93 & 0.87 & 0.93 & 1.00 & 0.87 & 1.00 & & & & & & & & & & & & & & & & & & & & & & \\
\hline RS7 & 0.93 & 0.87 & 0.81 & 0.87 & 1.00 & 0.87 & 1.00 & & & & & & & & & & & & & & & & & & & & & \\
\hline RS8 & 0.81 & 0.87 & 0.81 & 0.75 & 0.75 & 0.75 & 0.75 & 1.00 & & & & & & & & & & & & & & & & & & & & \\
\hline RS9 & 0.93 & 0.87 & 0.93 & 1.00 & 0.87 & 1.00 & 0.87 & 0.75 & 1.00 & & & & & & & & & & & & & & & & & & & \\
\hline RS10 & 0.81 & 0.75 & 0.68 & 0.75 & 0.75 & 0.75 & 0.75 & 0.75 & 0.75 & \begin{tabular}{|l|}
1.00 \\
\end{tabular} & & & & & & & & & & & & & & & & & & \\
\hline RS11 & 0.81 & 0.75 & 0.68 & 0.75 & 0.75 & 0.75 & 0.75 & 0.75 & 0.75 & \begin{tabular}{|l|}
0.75 \\
\end{tabular} & 1.00 & & & & & & & & & & & & & & & & & \\
\hline RS12 & 0.75 & 0.68 & 0.62 & 0.68 & 0.81 & 0.68 & 0.81 & 0.68 & 0.68 & 0.56 & 0.56 & 1.00 & & & & & & & & & & & & & & & & \\
\hline RS13 & 0.93 & 0.87 & 0.81 & 0.87 & 0.87 & 0.87 & 0.87 & 0.87 & 0.87 & \begin{tabular}{|l|}
0.75 \\
\end{tabular} & 0.75 & 0.81 & 1.00 & & & & & & & & & & & & & & & \\
\hline RS14 & 0.87 & 0.93 & 0.87 & 0.81 & 0.81 & 0.81 & 0.81 & 0.93 & 0.81 & 0.81 & 0.81 & 0.62 & 0.81 & 1.00 & & & & & & & & & & & & & & \\
\hline RS15 & 0.87 & 0.81 & 0.75 & 0.82 & 0.81 & 0.81 & 0.81 & 0.68 & 0.81 & 0.68 & 0.68 & 0.62 & 0.81 & \begin{tabular}{|l|}
0.75 \\
\end{tabular} & 1.00 & & & & & & & & & & & & & \\
\hline RS16 & 0.75 & 0.68 & 0.75 & 0.81 & 0.68 & 0.81 & 0.68 & 0.68 & 0.81 & 0.68 & 0.68 & 0.62 & 0.68 & 0.75 & 0.62 & 1.00 & & & & & & & & & & & & \\
\hline RS17 & 0.68 & 0.62 & 0.68 & 0.75 & 0.62 & 0.75 & 0.62 & 0.62 & 0.75 & \begin{tabular}{|l|}
0.75 \\
\end{tabular} & 0.62 & 0.43 & 0.62 & \begin{tabular}{|l|}
0.68 \\
\end{tabular} & 0.68 & \begin{tabular}{|l|}
0.81 \\
\end{tabular} & 1.00 & & & & & & & & & & & \\
\hline RS18 & 0.87 & 0.81 & 0.75 & 0.81 & 0.81 & 0.81 & 0.81 & 0.81 & 0.81 & 0.68 & 0.68 & 0.87 & 0.93 & 0.75 & 0.75 & \begin{tabular}{|l|}
0.62 \\
\end{tabular} & 0.56 & 1.00 & & & & & & & & & & \\
\hline RS19 & 0.81 & 0.87 & 0.81 & 0.75 & 0.75 & 0.75 & 0.75 & 0.87 & 0.75 & \begin{tabular}{|l|}
0.75 \\
\end{tabular} & 0.75 & 0.56 & 0.75 & \begin{tabular}{|l|}
0.93 \\
\end{tabular} & \begin{tabular}{|l|}
0.81 \\
\end{tabular} & \begin{tabular}{|l|}
0.68 \\
\end{tabular} & 0.75 & 0.68 & 1.00 & & & & & & & & & \\
\hline RS20 & 0.93 & 0.87 & 0.81 & 0.87 & 0.87 & 0.87 & 0.87 & 0.75 & 0.87 & 0.75 & 0.75 & 0.68 & 0.87 & 0.81 & 0.93 & 0.68 & 0.75 & 0.81 & 0.87 & \begin{tabular}{|l|}
1.00 \\
\end{tabular} & & & & & & & & \\
\hline RS21 & 0.93 & 0.87 & 0.81 & 0.87 & 0.87 & 0.87 & 0.87 & 0.87 & 0.87 & 0.75 & 0.75 & 0.81 & 1.00 & 0.81 & 0.81 & 0.68 & 0.62 & 0.93 & 0.75 & \begin{tabular}{|l|}
0.87 \\
\end{tabular} & 1.00 & & & & & & & \\
\hline RS22 & 0.93 & 0.87 & 0.81 & 0.87 & 0.87 & 0.87 & 0.87 & 0.87 & 0.87 & 0.87 & 0.87 & 0.68 & 0.87 & 0.93 & 0.81 & 0.81 & 0.75 & 0.81 & 0.87 & \begin{tabular}{|l|}
0.87 \\
\end{tabular} & 0.87 & 1.00 & & & & & & \\
\hline RS23 & 0.81 & 0.75 & 0.81 & 0.87 & 0.75 & 0.87 & 0.75 & 0.75 & 0.87 & \begin{tabular}{|l|}
0.75 \\
\end{tabular} & 0.75 & 0.56 & 0.75 & 0.81 & 0.68 & \begin{tabular}{|l|}
0.93 \\
\end{tabular} & 0.87 & 0.68 & 0.75 & \begin{tabular}{|l|}
0.75 \\
\end{tabular} & 0.75 & \begin{tabular}{|l|}
0.87 \\
\end{tabular} & \begin{tabular}{|l|}
1.00 \\
\end{tabular} & & & & & \\
\hline RS24 & 0.87 & 0.93 & 0.87 & 0.81 & 0.81 & 0.81 & 0.81 & 0.81 & 0.81 & \begin{tabular}{|l|}
0.68 \\
\end{tabular} & 0.68 & 0.62 & 0.81 & \begin{tabular}{|l|}
0.87 \\
\end{tabular} & \begin{tabular}{|l|}
0.87 \\
\end{tabular} & 0.62 & 0.56 & \begin{tabular}{|l|}
0.75 \\
\end{tabular} & 0.81 & \begin{tabular}{|l|}
0.81 \\
\end{tabular} & 0.81 & 0.81 & 0.68 & 1.00 & & & & \\
\hline RS25 & 0.87 & 0.93 & 0.87 & 0.81 & 0.81 & 0.81 & 0.81 & 0.81 & 0.81 & \begin{tabular}{|l|}
0.68 \\
\end{tabular} & 0.68 & 0.62 & 0.81 & \begin{tabular}{|l|}
0.87 \\
\end{tabular} & \begin{tabular}{|l|}
0.87 \\
\end{tabular} & \begin{tabular}{|l|}
0.62 \\
\end{tabular} & 0.56 & 0.75 & 0.81 & \begin{tabular}{|l|}
0.81 \\
\end{tabular} & 0.81 & \begin{tabular}{|l|}
0.81 \\
\end{tabular} & \begin{tabular}{|l|}
0.68 \\
\end{tabular} & \begin{tabular}{|l|}
1.00 \\
\end{tabular} & 1.00 & & & \\
\hline RS26 & 0.81 & 0.75 & 0.68 & 0.75 & 0.75 & 0.75 & 0.75 & 0.75 & 0.75 & \begin{tabular}{|l|}
0.87 \\
\end{tabular} & 0.75 & 0.56 & 0.75 & \begin{tabular}{|l|}
0.81 \\
\end{tabular} & \begin{tabular}{|l|}
0.68 \\
\end{tabular} & \begin{tabular}{|l|}
0.68 \\
\end{tabular} & 0.62 & 0.68 & 0.75 & \begin{tabular}{|l|}
0.75 \\
\end{tabular} & 0.75 & 0.87 & 0.75 & \begin{tabular}{|l|}
0.68 \\
\end{tabular} & 0.68 & 1.00 & & \\
\hline RS27 & 1.00 & 0.93 & 0.87 & 0.93 & 0.93 & 0.93 & 0.93 & 0.81 & 0.93 & \begin{tabular}{|l|}
0.81 \\
\end{tabular} & 0.81 & 0.75 & 0.93 & \begin{tabular}{|l|}
0.87 \\
\end{tabular} & \begin{tabular}{|l|}
0.87 \\
\end{tabular} & \begin{tabular}{|l|}
0.75 \\
\end{tabular} & 0.68 & 0.87 & 0.81 & \begin{tabular}{|l|}
0.93 \\
\end{tabular} & 0.93 & 0.93 & 0.81 & \begin{tabular}{|l|}
0.87 \\
\end{tabular} & 0.87 & 0.81 & 1.00 & \\
\hline RS28 & 0.87 & 0.81 & 0.75 & 0.81 & 0.81 & 0.81 & 0.81 & 0.68 & 0.81 & 0.68 & 0.81 & 0.62 & 0.81 & \begin{tabular}{|l|}
0.75 \\
\end{tabular} & \begin{tabular}{|l|}
0.75 \\
\end{tabular} & \begin{tabular}{|l|}
0.75 \\
\end{tabular} & 0.68 & 0.75 & 0.68 & \begin{tabular}{|l|}
0.81 \\
\end{tabular} & 0.81 & 0.81 & 0.81 & \begin{tabular}{|l|} 
\\
\end{tabular} & 0.75 & 0.68 & 0.87 & 1.00 \\
\hline
\end{tabular}


Table.4 Relative mobility ( $\mathrm{Rm})$ values of peroxidase of $R$. solani isolates

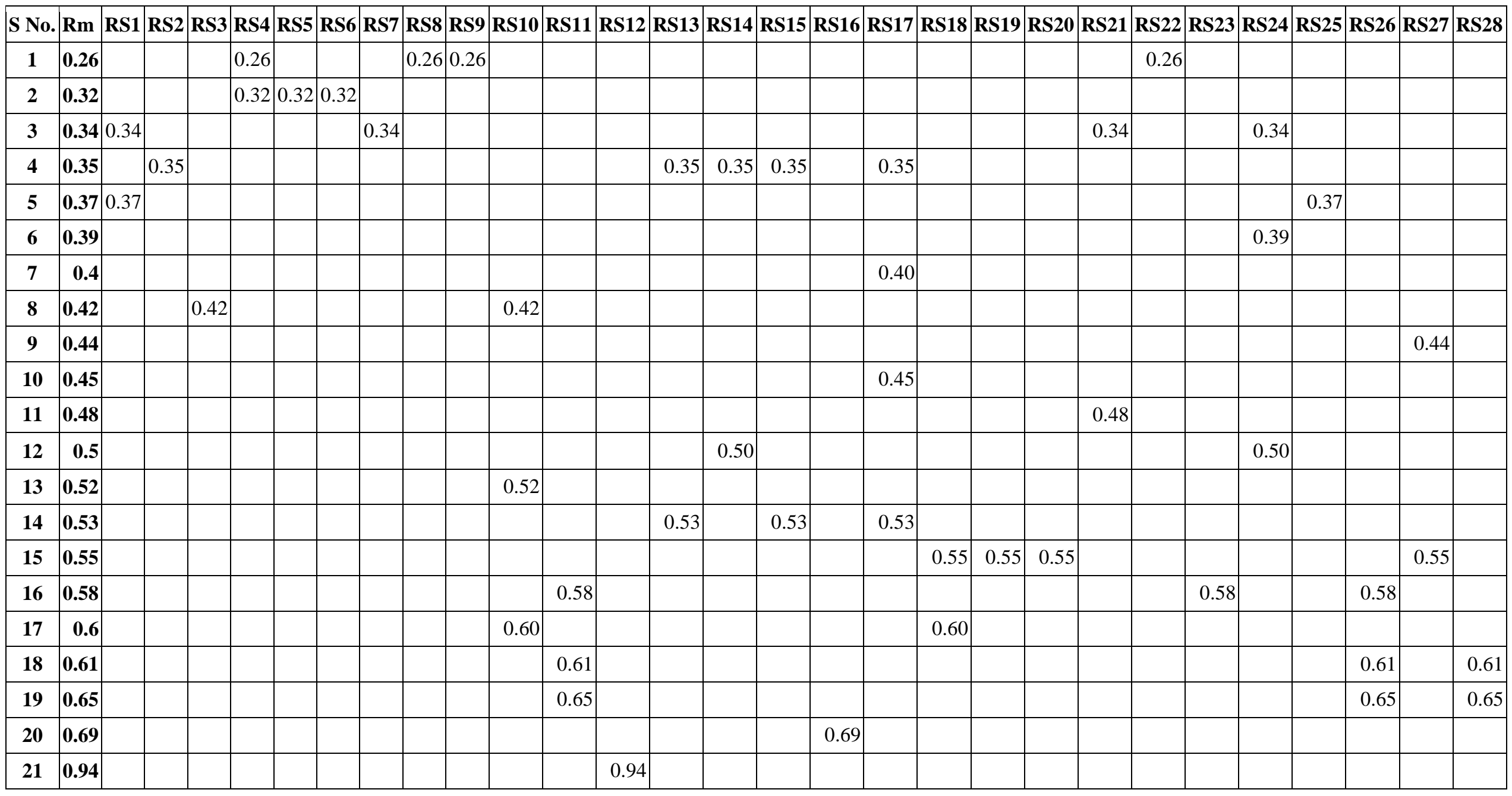


Table.5 Similarity index values of peroxidase patterns of $R$. solani isolates

\begin{tabular}{|c|c|c|c|c|c|c|c|c|c|c|c|c|c|c|c|c|c|c|c|c|c|c|c|c|c|c|c|c|}
\hline & RS1 & \begin{tabular}{|l|} 
RS2 \\
\end{tabular} & RS3 & RS4 & RS5 1 & RS6 & \begin{tabular}{|l|} 
RS7 \\
\end{tabular} & RS8 & \begin{tabular}{|l|l|} 
RS9 \\
\end{tabular} & \begin{tabular}{|l|} 
RS10 \\
\end{tabular} & RS11 & RS12 & RS13 & RS14 & RS15 & RS16 & RS17 & RS18 & RS19 & \begin{tabular}{|l|} 
RS20 \\
\end{tabular} & \begin{tabular}{|l|} 
RS21 \\
\end{tabular} & RS22 & \begin{tabular}{|l|} 
RS23 \\
\end{tabular} & \begin{tabular}{|l|} 
RS24 \\
\end{tabular} & RS25 & RS26 & RS27 & RS28 \\
\hline RS1 & 1.00 & & & & & & & & & & & & & & & & & & & & & & & & & & & \\
\hline RS2 & 0.85 & 1.00 & & & & & & & & & & & & & & & & & & & & & & & & & & \\
\hline RS3 & 0.85 & 0.90 & 1.00 & & & & & & & & & & & & & & & & & & & & & & & & & \\
\hline RS4 & 0.80 & 0.85 & 0.85 & 1.00 & & & & & & & & & & & & & & & & & & & & & & & & \\
\hline RS5 & 0.85 & 0.90 & 0.90 & 0.95 & 1.00 & & & & & & & & & & & & & & & & & & & & & & & \\
\hline RS6 & 0.85 & 0.90 & 0.90 & 0.95 & 0.01 & 1.00 & & & & & & & & & & & & & & & & & & & & & & \\
\hline RS7 & 0.95 & 0.90 & 0.90 & 0.85 & 0.90 & \begin{tabular}{|l|}
0.90 \\
\end{tabular} & 1.00 & & & & & & & & & & & & & & & & & & & & & \\
\hline \begin{tabular}{|l|} 
RS8 \\
\end{tabular} & \begin{tabular}{|l|}
0.90 \\
\end{tabular} & 0.95 & 0.95 & 0.90 & 0.95 & 0.95 & 0.95 & 1.00 & & & & & & & & & & & & & & & & & & & & \\
\hline RS9 & 0.90 & 0.95 & 0.95 & 0.90 & 0.95 & 0.95 & 0.95 & 0.01 & 1.00 & & & & & & & & & & & & & & & & & & & \\
\hline RS10 & 0.76 & 0.90 & 0.90 & 0.76 & 0.80 & 0.80 & 0.80 & 0.85 & \begin{tabular}{|l|}
0.85 \\
\end{tabular} & 1.00 & & & & & & & & & & & & & & & & & & \\
\hline RS11 & 0.76 & 0.80 & 0.80 & 0.76 & 0.80 & 0.80 & 0.80 & 0.85 & 0.85 & 0.71 & 1.00 & & & & & & & & & & & & & & & & & \\
\hline RS12 & 0.85 & 0.90 & 0.90 & 0.85 & 0.90 & 0.90 & 0.90 & 0.95 & 0.95 & 0.80 & 0.80 & 1.00 & & & & & & & & & & & & & & & & \\
\hline RS13 & 0.80 & 0.85 & 0.85 & 0.80 & 0.85 & 0.85 & 0.85 & 0.90 & 0.90 & 0.76 & 0.76 & 0.85 & 1.00 & & & & & & & & & & & & & & & \\
\hline RS14 & 0.80 & 0.85 & 0.85 & 0.80 & 0.85 & 0.85 & 0.85 & 0.90 & 0.90 & 0.76 & 0.76 & 0.85 & 0.90 & 1.00 & & & & & & & & & & & & & & \\
\hline RS15 & 0.80 & 0.85 & 0.85 & 0.80 & 0.85 & 0.85 & 0.85 & 0.90 & \begin{tabular}{|l|}
0.90 \\
\end{tabular} & 0.76 & 0.76 & 0.85 & 0.01 & 0.90 & 1.00 & & & & & & & & & & & & & \\
\hline RS16 & 0.85 & 0.90 & 0.90 & 0.85 & 0.90 & 0.90 & 0.90 & 0.95 & 0.95 & 0.80 & 0.80 & 0.90 & 0.85 & 0.85 & 0.85 & 1.00 & & & & & & & & & & & & \\
\hline RS17 & 0.71 & 0.76 & 0.76 & 0.71 & 0.76 & 0.76 & 0.76 & 0.80 & \begin{tabular}{|l|}
0.80 \\
\end{tabular} & 0.66 & 0.66 & 0.76 & 0.90 & 0.80 & 0.90 & \begin{tabular}{|l|}
0.76 \\
\end{tabular} & 1.00 & & & & & & & & & & & \\
\hline RS18 & \begin{tabular}{|l|}
0.80 \\
\end{tabular} & 0.85 & 0.85 & 0.80 & 0.85 & 0.85 & 0.85 & 0.90 & \begin{tabular}{|l|}
0.90 \\
\end{tabular} & 0.85 & 0.76 & 0.85 & 0.80 & 0.80 & 0.80 & 0.85 & 0.71 & 1.00 & & & & & & & & & & \\
\hline RS19 & 0.85 & 0.90 & 0.90 & 0.85 & 0.90 & 0.90 & 0.90 & 0.95 & 0.95 & 0.80 & \begin{tabular}{|l|}
0.80 \\
\end{tabular} & 0.90 & \begin{tabular}{|l|}
0.85 \\
\end{tabular} & 0.85 & 0.85 & 0.90 & 0.76 & 0.95 & 1.00 & & & & & & & & & \\
\hline RS20 & 0.85 & 0.90 & 0.90 & 0.85 & 0.90 & 0.90 & 0.90 & 0.95 & 0.95 & 0.80 & \begin{tabular}{|l|}
0.80 \\
\end{tabular} & 0.90 & 0.85 & 0.85 & 0.85 & 0.90 & 0.76 & 0.95 & 0.01 & 1.00 & & & & & & & & \\
\hline RS21 & \begin{tabular}{|l|}
0.90 \\
\end{tabular} & 0.85 & 0.85 & 0.80 & 0.85 & 0.85 & 0.95 & 0.90 & \begin{tabular}{|l|}
0.90 \\
\end{tabular} & 0.76 & \begin{tabular}{|l|}
0.76 \\
\end{tabular} & 0.85 & \begin{tabular}{|l|}
0.80 \\
\end{tabular} & 0.80 & \begin{tabular}{|l|} 
\\
\end{tabular} & \begin{tabular}{|l|}
0.85 \\
\end{tabular} & 0.71 & 0.80 & 0.85 & 0.85 & 1.00 & & & & & & & \\
\hline RS22 & 0.90 & 0.95 & 0.95 & 0.90 & 0.95 & 0.95 & 0.95 & 0.01 & 0.01 & 0.85 & 0.85 & 0.95 & 0.90 & 0.90 & 0.90 & \begin{tabular}{|l|}
0.95 \\
\end{tabular} & 0.80 & 0.90 & 0.95 & 0.95 & 0.90 & 1.00 & & & & & & \\
\hline RS23 & 0.85 & 0.90 & 0.90 & 0.85 & 0.90 & 0.90 & 0.90 & 0.95 & 0.95 & 0.80 & 0.90 & 0.90 & \begin{tabular}{|l|}
0.85 \\
\end{tabular} & 0.85 & 0.85 & \begin{tabular}{|l|}
0.90 \\
\end{tabular} & 0.76 & 0.85 & 0.90 & 0.90 & 0.85 & 0.95 & 1.00 & & & & & \\
\hline RS24 & 0.85 & 0.80 & 0.80 & 0.76 & 0.80 & 0.80 & 0.90 & 0.85 & 0.85 & $\begin{array}{l}0.71 \\
\end{array}$ & 0.71 & 0.80 & \begin{tabular}{|l|}
0.76 \\
\end{tabular} & 0.85 & 0.76 & $\begin{array}{l}0.80 \\
\end{array}$ & 0.66 & 0.76 & 0.80 & 0.80 & 0.85 & 0.85 & 0.80 & 1.00 & & & & \\
\hline RS25 & 0.95 & 0.90 & 0.90 & 0.85 & 0.90 & 0.90 & 0.90 & 0.95 & 0.95 & 0.80 & 0.80 & 0.90 & 0.85 & 0.85 & 0.85 & \begin{tabular}{|l|}
0.90 \\
\end{tabular} & 0.76 & 0.85 & $\begin{array}{l}0.90 \\
\end{array}$ & 0.90 & 0.85 & 0.95 & 0.90 & 0.80 & 1.00 & & & \\
\hline RS26 & 0.76 & 0.80 & 0.80 & 0.76 & 0.80 & 0.80 & 0.80 & 0.85 & 0.85 & 0.71 & 0.01 & 0.80 & 0.76 & 0.76 & 0.76 & 0.80 & 0.66 & \begin{tabular}{|l|l|} 
\\
\end{tabular} & 0.80 & 0.80 & 0.76 & 0.85 & 0.90 & 0.71 & 0.80 & 1.00 & & \\
\hline RS27 & 0.80 & 0.85 & 0.85 & 0.80 & 0.85 & 0.85 & 0.85 & 0.90 & 0.90 & 0.76 & 0.76 & 0.85 & \begin{tabular}{|l|}
0.80 \\
\end{tabular} & 0.80 & 0.80 & \begin{tabular}{|l|}
0.85 \\
\end{tabular} & 0.71 & 0.90 & 0.95 & 0.95 & 0.80 & 0.90 & 0.85 & 0.76 & 0.85 & 0.76 & 1.00 & \\
\hline \begin{tabular}{|l|} 
RS28 \\
\end{tabular} & 0.80 & 0.85 & 0.85 & 0.80 & 0.85 & 0.85 & 0.85 & 0.90 & \begin{tabular}{|c|}
0.90 \\
\end{tabular} & $\begin{array}{ll}0.76 \\
\end{array}$ & \begin{tabular}{|l|}
0.95 \\
\end{tabular} & 0.85 & \begin{tabular}{|l|}
0.80 \\
\end{tabular} & \begin{tabular}{|l|}
0.80 \\
\end{tabular} & 0.80 & \begin{tabular}{|l|}
0.85 \\
\end{tabular} & 0.71 & 0.80 & 0.85 & 0.85 & 0.80 & 0.90 & 0.85 & \begin{tabular}{ll|}
0.76 \\
\end{tabular} & 0.85 & \begin{tabular}{|l|}
0.95 \\
\end{tabular} & 0.80 & 1.00 \\
\hline
\end{tabular}


Table.6 Variation in quantity of polyphenol oxidase content in the mycelium of $R$. solani isolates

\begin{tabular}{|c|l|c|}
\hline S.No & Isolate & OD value at 410 nm \\
\hline 1 & RS1 & 0.009 \\
\hline 2 & RS2 & 0.012 \\
\hline 3 & RS3 & 0.008 \\
\hline 4 & RS4 & 0.047 \\
\hline 5 & RS5 & 0.021 \\
\hline 6 & RS6 & 0.025 \\
\hline 7 & RS7 & 0.013 \\
\hline 8 & RS8 & 0.031 \\
\hline 9 & RS9 & 0.015 \\
\hline 10 & RS10 & 0.034 \\
\hline 11 & RS11 & 0.080 \\
\hline 12 & RS12 & 0.071 \\
\hline 13 & RS13 & 0.005 \\
\hline 14 & RS14 & 0.024 \\
\hline 15 & RS15 & 0.024 \\
\hline 16 & RS16 & 0.074 \\
\hline 17 & RS17 & 0.053 \\
\hline 18 & RS18 & 0.024 \\
\hline 19 & RS19 & 0.012 \\
\hline 20 & RS20 & 0.021 \\
\hline 21 & RS21 & 0.004 \\
\hline 22 & RS22 & 0.012 \\
\hline 23 & RS23 & 0.012 \\
\hline 24 & RS24 & 0.009 \\
\hline 25 & RS25 & 0.012 \\
\hline 26 & RS26 & 0.022 \\
\hline 27 & RS27 & 0.024 \\
\hline 28 & RS28 (Rice) & 0.097 \\
\hline & CD 5\% & 0.026 \\
\hline & SE(d) & 0.013 \\
\hline & SE(m) & 0.009 \\
\hline & CV & \\
\hline & & 561 \\
\hline
\end{tabular}




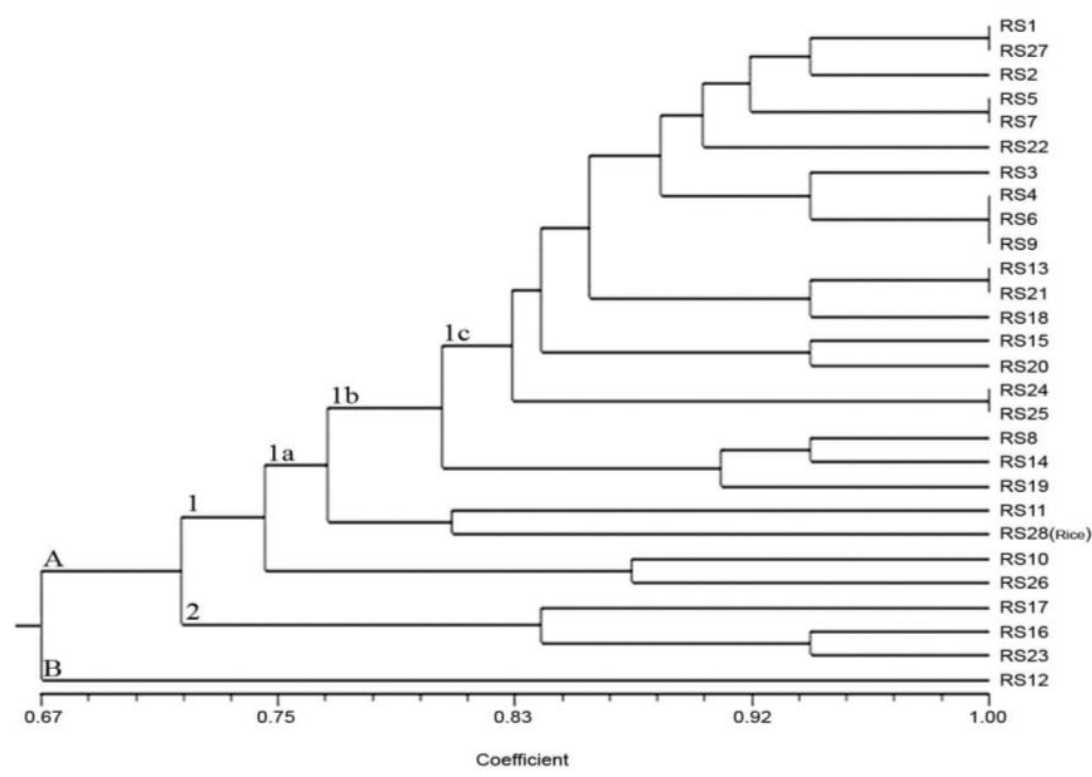

Figure 1. Grouping of R. solani isolates based on similarity index of esterase enzyme

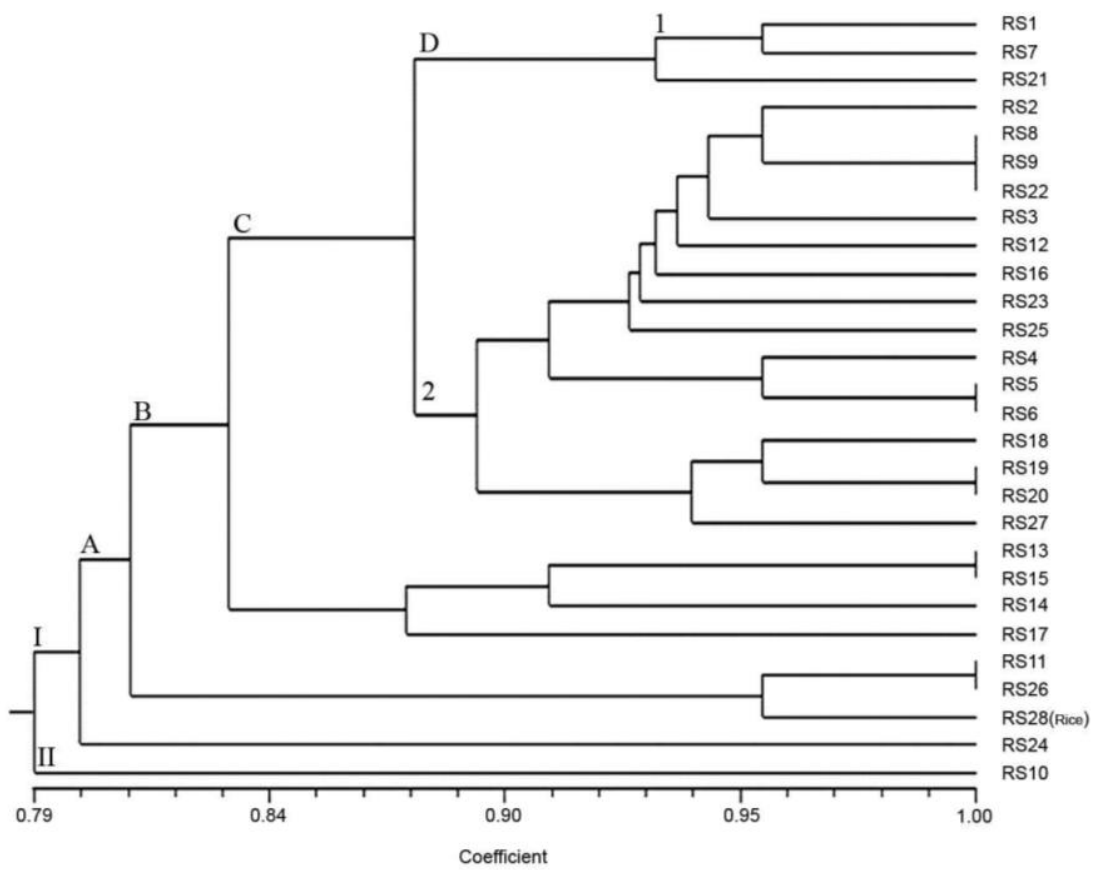

Figure 2 Grouping of $R$. solani isolates based on similarity index of peroxidase enzyme 
Int.J.Curr.Microbiol.App.Sci (2018) 7(1): 3321-3338
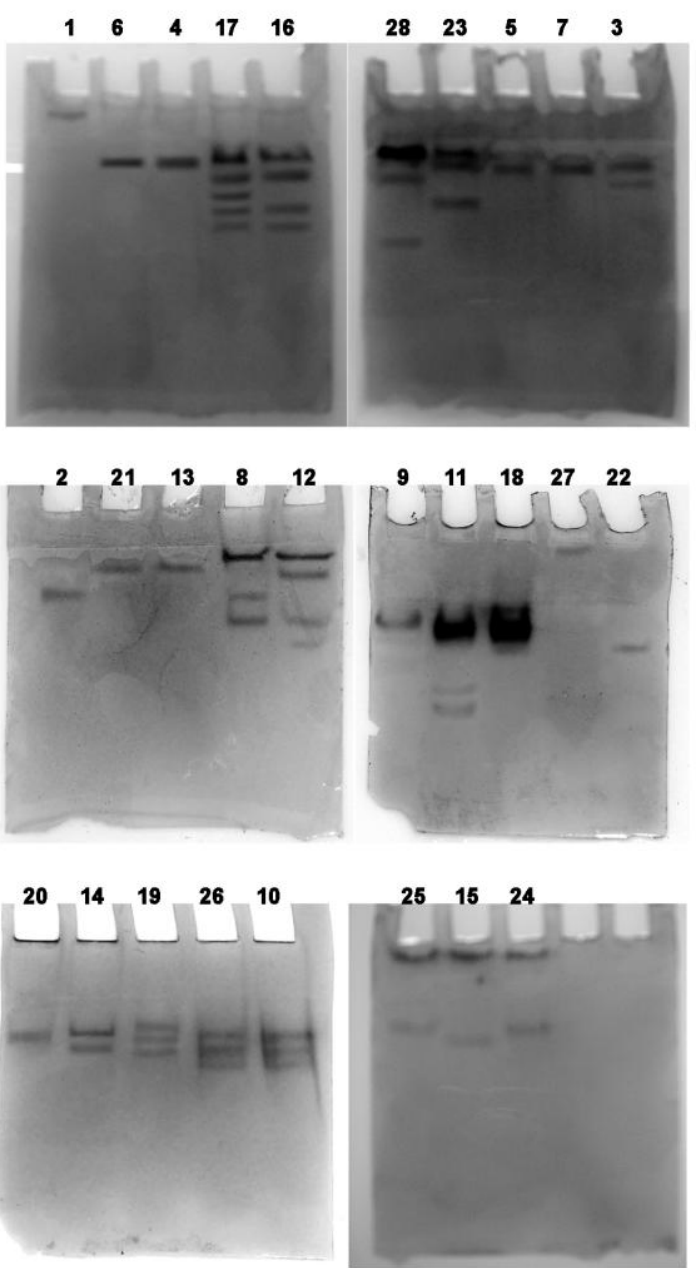

Plate 1 Esterase banding pattern of $R$. solani isolates 


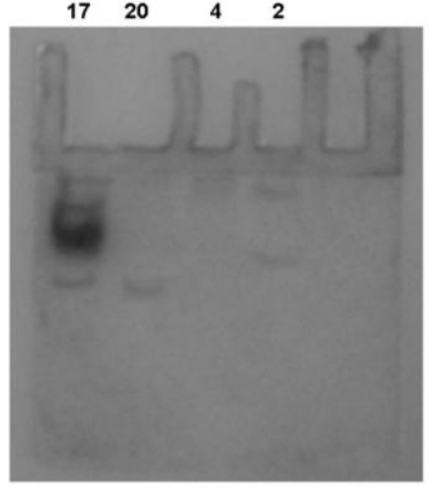

$\begin{array}{lllllll}18 & 8 & 19 & 22 & 28 & 26 & 11\end{array}$

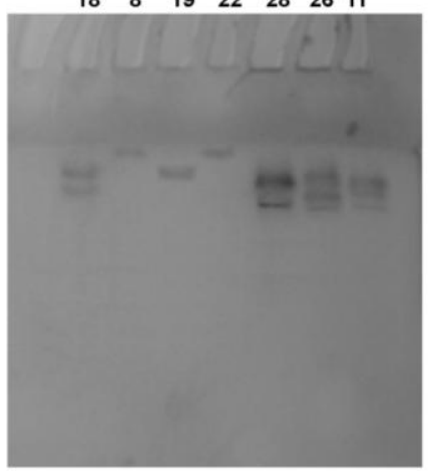

1216

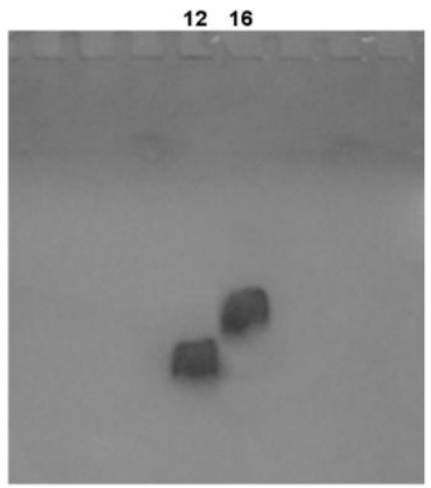

Plate 2 Peroxidase banding pattern of $\boldsymbol{R}$. solani isolates

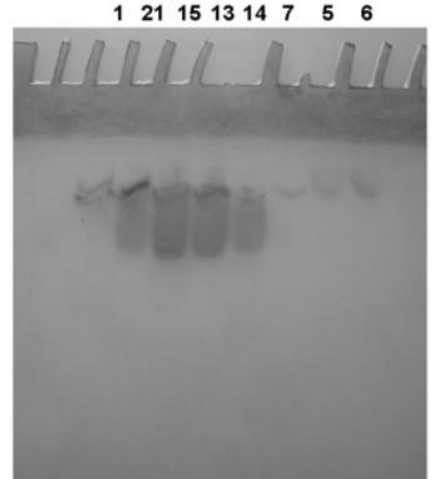

$\begin{array}{lllllll}3 & 24 & 23 & 25 & 10 & 27 & 9\end{array}$

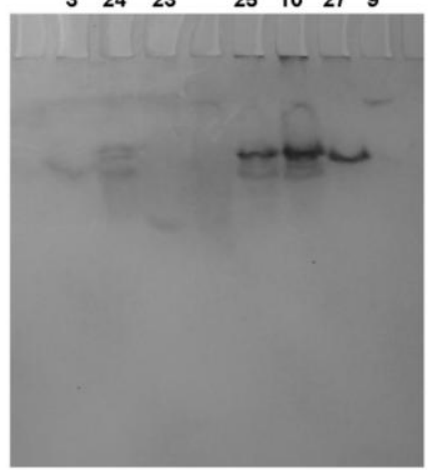

These results corroborate with the findings of Upamanyu et al., (2005) who observed differences in esterase isozyme patterns of $R$. solani isolates from french beans in different parts of Himachal Pradesh. Esterases are often used to measure genetic variation, yet they may be influenced by external factors (Perrotey et al.,2002). Isozyme analysis revealed higher polymorphism among $R$. solani isolates using esterase (EST) and 
isolates, with two avirulent isolates loosely linked to this at 0.13 similarity. Isozyme systems of esterases ( both $\alpha$ and $\beta$ ) and 6phosphogluconic dehydrogenase could be used to fingerprint the individual isolates (Neeraja et al.,2002). Seema, et al., (2013) reported that the isozyme profile of R.solani isolates collected from tobacco seedlings indicated the existence of variations among the isolates from different geographical area. Similarly, variations among different isolates of Rhizoctonia bataticola from chick pea were studied in respect of isozymes esterases and peroxidases by Pawar and Ingle (2014) and the R.solani isolates from cotton (Mikhail, et al., 2009). Mondal et al., (2013) observed marked variation in peroxidase activity among the $R$. solani isolates and among different isolates of Fusarium ciceri by Pawar and Mane (2014).

Electrophoresis results of present investigation revealed variation in position, width and intensity of bands and the result was in the line of (Amany and Ellil, 2005) who reported that analysis of esterase pattern of R1 has shown 4 distinct bands but for R4, 3 distinct bands were presented and a weak fourth band appeared, which is the only band similar to that of R1. Results from esterase isozymes analysis for $R$. solani suggested that the morphological traits are genetically based. This morphological variant may be due probably to one or more genetic blocks used. It was shown that the morphological trait was related to the absence or presence of one enzyme. Isozyme analysis has been widely used as a tool to study genetic diversity in AGs and within subgroups of $R$. solani (Micales et al.,1992). Jin and Korpradiskul (1998) differentiated 23 isolates of $R$. solani AG1 into 3 groups of I, II and III based on cluster analysis using data of 7 enzymes systems. Likewise, Laroche et al., (1992) used enzymes analysis to distinguish AGs 3 and 9 in $R$. solani. Kaufman and Rothrock
(1995) also differentiated AG11 isolates from Australia and Arkansas using isozymes analysis. Isozyme variation and genetic relatedness in binucleate Rhizoctonia species were studied by Damaj et al., (1993). Mohammadi et al., (2003) used isozymes analysis and total soluble protein profiles to measure the genetic diversity of the Iranian $R$. solani isolate AG1.

Using isozyme analysis sufficient variation within the asexual state of $R$. solani AG-2 was found to allow inter - isolate and inter - group comparisons (Liu et al.,1990). Isozyme analysis / isozyme patterns studied in this investigation revealed that the isolates of $R$. solani showed considerable diversity in the production of enzyme which plays a major role in pathogenicity and confirming the previous observations, where electrophoretic patterns of isozymes provided a good indication of genetic diversity among the isolates. The results obtained from isozyme analysis in this study suggested that isozyme analysis could be useful in genetic diversity studies and identification of various $R$. solani isolates. Similar results were observed by Mohammadi et al., (2003, 2004), who used isozymes and total soluble protein in studying the genetic diversity of several isolates of $R$. solani and Fusarium oxysporum isolated from different locations in Iran.

Several studies on isozyme patterns have provided good indications of the genetic diversity among Rhizoctonia anastomosis groups and phenotypic subgroups, thereby reconfirming the genetic basis of the anastomosis grouping, (Meisong and Korpradiskul, 1999). Isozyme studies have also provided evidence for several genetically distinct subgroups (6 within AGI and 5 within AG2) and some isozyme alleles and loci have been identified as markers for each subgroup (Liu and Sinclair, 1992 and Liu et al.,1990). 
In conclusion, the results revealed that Isozyme patterns provide good indications of the genetic diversity among Rhizoctonia anastomosis groups and phenotypic subgroups. The isolates of $R$. solani showed considerable diversity in the production of enzyme which plays a major role in pathogenicity and confirming the previous observations, where electrophoretic patterns of isozymes provided a good indication of genetic diversity among the isolates. Differences in electrophoretic isozyme patterns are an indication, in part, of genomic differences between isolates, but environmental circumstances affect the isozymes that are synthesized. The results obtained from isozyme analysis in this study suggested that that isozyme analysis could be useful in genetic diversity studies and identification of various $R$. solani isolates.

\section{Acknowledgements}

Main author is thankful to Head, Department of Plant Pathology, College of Agriculture, Rajendranagar, Hyderabad, Telengana State for providing basic facility for studying the morphological characters of $R$. solani isolates. And also to the Head, Institute of Agricultural Biotechnology, College of Agriculture, Rajendranagar for providing facilities for studying variability in isozyme patterns among $R$. solani isolates from maize and rice.

\section{References}

Akhtar, J., Jha, V.K., Kumar, A. and Lal, H.C.(2009). Occurrence of banded leaf and sheath blight of maize in Jharkhand with reference to diversity in Rhizoctonia solani. Asian Journal of Agricultural Sciences. 1(2): 32-35.

Amany, H.A. and Abo, E. (2005). Biochemical changes and pathogenicity variations related to Esterase Polymorphism for Morphological Traits of Rhizoctonia solani. Egyptian Journal of Phytopathology. 33(1): 33-44.
Bosland, P.W. and Williams, P.H. (1987). An evaluation of Fusarium oxysporium from crucifers based on pathogenicity, isozyme polymorphism, vegetative compatibility and geographic origin. Canadian Journal of Botany. 65: 2067-2073.

Damaj, M., Jabaji-Hare, S.H. and Charest, P.M. (1993). Isozyme variation and genetic relatedness in binucleate Rhizoctonia species. Phytopathology. 83 : 864-871.

Erhan Astarci. (2003). Production and Biochemical Characterization of Polyphenol Oxidase from Thermomyces lanuginosus. Msc Thesis. The Middle East Technical University, Ankara 06531 Turkey, 89 pages.

Horvath, B.J. and Vargas, J.M. (2004). Genetic variation among Colletotrichum graminicola isolates from four hosts using isozyme analysis. Plant Disease. 88: 402-406.

Jin MeiSong. and Korpradiskul, V.(1998). Isozyme analysis of genetic diversity among isolates of Rhizoctonia solani anastomosis group 1-IA (AG1-IA). Mycosystema. 17(4): 331-338.

Kaufman, P. and Rothrock, C.S. (1995). Evaluation of isolate diversity of Rhizoctonia solani subgroup. Phytopathology. 85 : 1125 (Abst.).

Laemmli, U.K. (1970). Cleavage of structural proteins during the assembly of the head of bacteriophage T4. Nature. 227 : 680-685.

Laroche, J.P., Jabaji-Hare, S.H. and Charest, P.M.(1992). Differentiation of two anastomosis groups of Rhizoctonia solani by isozyme analysis. Phytopathology. 82(12) : 1387-1393.

Liu, Z.L., Nickrent, D.L. and Sinclair, J.B. (1990). Genetic relationship among isolates of Rhizoctonia solani anastomosis group 2 based on isozyme analysis. Canadian Journal of Plant Pathology. $12: 376-382$.

Liu, Z. L. and Sinclair, J.B. (1992). Genetic diversity of Rhizoctonia solani anastomosis group 2. Phytopathology. 82(7) : 778-787.

Mahmoud, Y.A.G., Gaafar, R.M. and Mubarak, H.M. (2007). Genetic diversity among Nile Delta isolates of Rhizoctonia solani Kuhn based on pathogenicity, compatibility, isozyme analysis and total protein pattern. Turkish Journal of Botany.31(1) : 19-29.

Meisong, J. and Kopradiskul, V. (1999). Isozyme 
analysis of genetic diversity among isolates of Rhizoctonia solani anastomosis group 1IA (AG1-IA). Mycosystema. 17: 331-338.

Micales, J.A., Bonde, M.R. and Peterson. V. (1992). Isozyme analysis in fungi taxonomy and molecular genetics. In : Arora Dk, RP elander and KG Mukerji (eds.). Handbook of applied Mycology, vol. 4 : Fungal Biotechnology, Marcel Dekker, Inc., New York. Pp. 57-79.

Micales, J.A. and Bonde, M.R.(1995). Isozymes : Methods and Applications. In : Molecular Methods in Plant Pathology (ed). R.P. Singh and U.S. Singh, pp. 115- 130.

Mikhail, M.S., Sabet, K.K., Omar, M.R., Hussein, E.M. and Kasem, Kh.K. (2009). Differentiation Among Cotton Rhizoctonia solani Isolates by Pathogenicity and Isozymes Electrophoresis In Egypt . $4^{\text {th }}$ Conference on Recent Technologies in Agriculture. pp:110-118.

Mondal, A., Dutta, S., Kuiry, S. P., Chakraborty, D., Nandi, S., Das, S., Ray, S. K. and Chaudhuri, S. (2013). The Biochemical constituents and Pectinase activities associated with the virulence of Rhizoctonia solani isolates in rice in West Bengal, India. African Journal of Agricultural Research. 8(23): 3029-3035.

Mohammadi, M., Banihashemi, M., Hedjaroude, G.A. and Rahimian, H.(2003). Genetic diversity among Iranian isolates of Rhizoctonia solani Kuhn anastomosis group 1 sub groups based on isozyme analysis and total soluble protein pattern. Journal of Phytopathology. 151(3) : 162-170.

Mohammadi, M., Aminipour, M. and Banihashemi, Z.(2004). Isozyme analysis and soluble mycelial protein pattern in Iranian isolates of several formae speciales of Fusarium oxysporum. Journal of Phytopathology. $152:$ 267-276.
Neeraja, C.N., Shenoy, V.V., Reddy, C.S. and Sarma, N.P. (2002). Isozyme polymorphism and virulence of Indian isolates of the rice sheath blight fungus. Mycopathologia. 156(2) : 101- 108 .

Sambrook, J., Fritsch, E.F. and Maniatis, T.(1989). Molecular cloning. A laboratory manual. Cold Spring Harbor Laboratory Press, New York.

Seema, M. and Punith, B. D. and Devaki, N. S. (2013) First report on isozyme analysis of Rhizoctonia solani infecting tobacco in Karnataka, India. JSSCM Journal, 2 (1). pp. 44-49.

Shaw, C.R. and Prasad, R.(1970).Starch gel electrophoresis of enzymes - A compilation of recipes. Biochemical Genetics. 4 : 297320 .

Pawar, N.B. and Ingle, Y.V. (2014). Protein and isozyme patterns of Rhizoctonia bataticola isolates causing chickpea root rot. The Bioscan An International Quarterly Journal of Life Sciences(Supplement on Plant Pathology). 9(3): 1165-1170.

Pawar, N. B. and Mane, S. S. (2014). Protein and isozyme patterns of Fusarium oxysporum $f$. sp. ciceri isolates causing chickpea wilt. Indian Phytopathology. 67(3): 234-237.

Perrotey, S., Klein, B., Madulo, L.G., Gallego, M. and Pesson, B. (2002). Variation of esterase electromorphs associated with blood meal digestion in phlebotomines and flies (Diptera : Psychodidae). Journal of Medical Entomology.39(5) : 720-2.

Upamanyu, S., Gupta, S.K. and Kaur, R. (2005). Variation in French bean isolates of Rhizoctonia solani kuhn. Journal of Mycology and Plant Pathology. 35: 168-173.

\section{How to cite this article:}

Madhavi, M., P. Narayan Reddy, K. Manohar and Aruna Kumari, Ch. 2018. Variability in Isozyme Patterns for Virulence among the Rhizoctonia solani Isolates Causing Banded Leaf and Sheath Blight in Maize. Int.J.Curr.Microbiol.App.Sci. 7(01): 3321-3338.

doi: https://doi.org/10.20546/ijcmas.2018.701.395 